\title{
Participation of farm women involved in chilli cultivation
}

\author{
SUPRIYA P. PATIL AND SHOBHA NAGNUR* \\ Department of Extension and Communication Management, College of Rural Home Science, University \\ of Agricultural Sciences, DHARWAD (KARNATAKA) INDIA
}

\begin{abstract}
Women comprise about 43 per cent of the global agricultural labour force. Their participation in agriculture and rural economies, vary considerably between and within regions. Even within regions their participation varies based on land holding status of farm/household and the crop cultivated by them. The present investigation was undertaken to study the socio- personal characteristics and participation level of women involved in chilli cultivation. This study was conducted in Kundgol taluk of Dharwad district in Karnataka purposively as it is the highest chilli growing area. Five villages were selected randomly and from each village 30 farm women were selected making a sample of 150. Personal interview method was used to collect the data and suitable statistical tools were used for analyzing the data. The study revealed that majority if the respondents were growing ByadagiKaddi variety of chilli. The respondents were mainly between the ages of 36-50 with low level of education. They were from joint and medium sized families. Their average land holding was less than five acres with an annual family income of less than Rs. 1,32,000. The extension participation was low while social participation was high.The participation index for pre sowing and sowing operations was 62.69 , for inter culture operations it was 61.63 and for harvesting and post harvesting operation it was 72.49. The overall index was 65.88 meaning that nearly 66 per cent of all activities are carried out by women, it being higher in post-harvest activities than other activities. A high participation implies that there is increasing feminization of agriculture. The programmes and policies of government often biased in favour of men should target farm women.
\end{abstract}

KeY Words : Participation, Farm women, Chilli cultivation

View Point Article : Patil, Supriya P. and Nagnur, Shobha (2016). Participation of farm women involved in chilli cultivation. Internat. J. Home Sci. Extn. \& Comm. Manage., 3 (1): 1-7.

Article History : Received : 23.06.2015; Revised : 03.12.2015; Accepted : 17.12.2015

\footnotetext{
* Author for correspondence (Email : shobha_nagnur@yahoo.com)
} 